\title{
BNKR-1 (Dhiren) - A newly released late duration high-yielding rice variety an alternative to Swarna (MTU 7029) for West Bengal, India
}

\author{
G. K. Mallick ${ }^{1 *}$, I. Dana ${ }^{2}$, K. Jana ${ }^{1}$, A. Ghosh ${ }^{3}$ and A. Biswas ${ }^{1}$ \\ ${ }^{1}$ Rice Research Station, Nutanchati, Bankura - 722 101, West Bengal, INDIA \\ ${ }^{2}$ Rice Research Station, Chinsurah, Hooghly, West Bengal, INDIA \\ ${ }^{3}$ Zonal Adaptive Research Station, Krishnanagar, Nadia, West Bengal, INDIA \\ *Corresponding author. E-mail: mallickgkgene@gmail.com
}

Received: May 11, 2014; Revised received: October 20, 2014; Accepted: December 11, 2014

\begin{abstract}
BNKR - I (Dhiren), a new late duration high yielding rice variety developed at Rice Research Station, Bankura, West Bengal, India was released by "State Variety Release Committee" (SVRC), West Bengal in 2011 for cultivation in irrigated late areas of West Bengal, India. Before release as BNKR - I (Dhiren), this rice culture completed three years of national testing (2008-2010) in the designation of CN 1340-76-1-BNKR 23-7-1 (IET 20760) and had been recommended for release in irrigated areas of Bihar and West Bengal under transplanted condition in $46^{\text {th }}$ National Group Meeting on Rice organized by Directorate of Rice Research (ICAR), Hyderabad, India during April 2011. It gave 7.65 to $12.12 \%$ yield advantage over national check in national level. Not only that this culture of rice tested extensively in the farm of Rice research Station, Bankura, West Bengal and farmer's field. It showed $11.64 \%$ and $19.30 \%$ yield advantage during 2006 and 2007 in observational trial, 10.44 to $14.38 \%$ yield advantage in on station yield trial during $2008-2010$ and 12.51 to $17.93 \%$ yield advantage in farmer's field during 2009 and 2010 over Swarna (MTU 7029), which is the most popular rice variety of West Bengal. BNKR - I (Dhiren) is non-lodging, non-shattering and late maturing variety (seed to seed : 142 days). It is moderately resistant to leaf blast, neck blast, brown spot, sheath rot and leaf folder. It's average yield is $5000-5500 \mathrm{~kg} \mathrm{ha}^{-1}$. Grain type is short bold. It is expected that BNKR - I (Dhiren) can be able to replace Swarna (MTU 7029), the most popular rice variety of West Bengal, India.
\end{abstract}

Keywords: Bankura, BNKR - I (Dhiren), IET 20760, late duration, Rice Variety, Swarna (MTU 7029)

Swarna (MTU 7029) is the most popular late duration rice variety of West Bengal, India. This variety has been extensively grown by the farmer's of West Bengal for a long time. Farmer's want to replace Swarna as it has become susceptible to different pest and diseases, but due to lack of suitable alternative farmer's till now continuing the cultivation of Swarna (MTU 7029) (Saha et. al. 2008),. There is a need to develop an alternative to Swarna (MTU 7029) with more yield and more resistant to different pest and diseases.

Since the systematic research on rice started, mostly hybridization and pedigree selection and to some extent backcross breeding have been adopted on developing improved HYV's (Shobha Rani et al., 2011). Previously many rice varieties developed in India through pedigree selection namely Vivek Dhan 82 (Sharma et al., 2003), Santosh (Thakur et al., 2003), Rajendra Mahsuri 1 (Sahai et. al 2004) etc. To develop a rice variety with high yield for irrigated late situation a cross was made in 2000 between IR42 (Female parent) and Patnai 23 (Male parent). A promising rice culture CN 1340-76-1-BNKR 23-7-1, was developed through the pedigree selection method. Before being nominated to the All India Coordinated trial for testing under Initial Varietal Trial (Late) as IET 20760 in 2008 , this rice culture was tested for consecutive two years for its yield during Kharif 2006 and Kharif 2007 in observational trials at the farm of Rice Research Station, Bankura, West Bengal, India. It showed $11.64 \%$ and $19.30 \%$ yield advantage over Swarna during Kharif 2006 and 2007 respectively. (Table 2).

It was tested for three years (IVT-L, 2008; AVT-IL, 2009; and AVT-2L 2010) through "All India Co-ordinated Rice Improvement Project" at 59 locations all over the country under the supervision of Directorate of Rice Research, Rajendranagar, Hyderabad. On the basis of All India Mean yield IET 20760 gave 7.65 to $12.12 \%, 9.30$ to $16.57 \%$ and 5.20 to $17.27 \%$ more yield than National, Regional and Local check respectively (Table 1). After three years of testing IET 20760 was recommended for release in irrigated areas of Bihar and West Bengal under transplanted condition in $46^{\text {th }}$ National Group Meeting on rice organized by Directorate of Rice Research (ICAR), Hyderabad in April, 2011. It was tested at Rice Research Station, Bankura, West Bengal through on-station yield trial for three years (2008 to 2010) and gave 10.44 to $14.38 \%$ yield advantage over Swarna (MTU 7029). Not only that it was also tested on 
Table 1. Yield Performance of IET 20760 (CN 1340-76-1-BNKR 23-7-1) in All India Coordinated Trials (Mean Basis) from 2008-2010 in comparison with checks.

\begin{tabular}{|c|c|c|c|c|c|c|c|}
\hline Name of trial & $\begin{array}{l}\text { Year of } \\
\text { testing }\end{array}$ & $\begin{array}{c}\text { No. of } \\
\text { location }\end{array}$ & $\begin{array}{c}\text { IET 20760 } \\
\left(\mathrm{kg} \mathrm{ha}^{-1}\right)\end{array}$ & $\begin{array}{c}\text { National } \\
\text { check } \\
\left(\mathrm{kg} \mathrm{ha}^{-1}\right)\end{array}$ & $\begin{array}{c}\text { Regional } \\
\text { check } \\
\left(\mathbf{k g ~ h a}^{-1}\right)\end{array}$ & $\begin{array}{c}\text { Local } \\
\text { check } \\
\left(\mathrm{kg} \mathrm{ha}^{-1}\right)\end{array}$ & C.D. \\
\hline IVT - L & $\begin{array}{c}2008 \\
\left(1^{\text {st }} \text { year }\right)\end{array}$ & 18 & 4893 & 4364 & 4305 & 4651 & 307 \\
\hline AVT $1-\mathrm{L}$ & $\begin{array}{c}2009 \\
\left(2^{\text {nd }} \text { year }\right)\end{array}$ & 19 & 5403 & 4862 & 4635 & 4948 & 326 \\
\hline \multirow[t]{2}{*}{ AVT $2-\mathrm{L}$} & $\begin{array}{c}2010 \\
\left(3^{\text {rd }} \text { year }\right)\end{array}$ & 22 & 5358 & 4977 & 4902 & 4569 & 326 \\
\hline & Mean & 59 & 5231 & 4753 & 4634 & 4716 & \\
\hline \multirow{4}{*}{$\begin{array}{l}\text { Percent increase or } \\
\text { decrease over the } \\
\text { checks }\end{array}$} & 2008 & & & $+12.12 *$ & $+13.65 *$ & +5.20 & \\
\hline & 2009 & & & $+11.12 *$ & $+16.57 *$ & $+9.19 *$ & \\
\hline & 2010 & & & $+7.65 *$ & $+9.30 *$ & $+17.27 *$ & \\
\hline & Mean & & & +10.06 & +12.88 & +11.11 & \\
\hline $\begin{array}{l}\text { Frequency in top } \\
\text { group (pooled for } 3 \\
\text { years) }\end{array}$ & & & $35 / 59$ & $24 / 59$ & $22 / 59$ & $30 / 59$ & \\
\hline
\end{tabular}

Note: * observed difference is significant at 0.05 level.

$1=$ Savitri used as national check in 2008 and 2009 and Swarna (MTU 7029) in 2010.

$2=$ Regional checks were Pooja (Eastern region), Salivahana (Western region) and Samba mahsuri (Southern region)

3 = Mahanadi, Tapaswini, Ranjit, Karjat-2, SYE-5, Rajendra, Asha etc. used as local checks in different states of India.

Table 2. Yield performance of IET 20760 (CN 1340-76-1-BNKR 23-7-1) in Comparison with Swarna in different trials in West Bengal, India.

\begin{tabular}{llccc}
\hline Year & Trial & $\begin{array}{c}\text { IET 20760 } \\
\left(\mathbf{k g ~ h a}^{-1}\right)\end{array}$ & $\begin{array}{c}\text { Swarna } \\
\left(\mathbf{k g ~ h a}^{-1}\right)\end{array}$ & $\begin{array}{c}\text { Yield increase over } \\
\text { Swarna (\%) }\end{array}$ \\
\hline 2006 & On-station observational trial & 4813 & 4311 & 11.64 \\
2007 & On-station observational trial & 6100 & 5113 & 19.30 \\
2008 & On-station yield trial & 5473 & 4785 & 14.38 \\
2009 & On-station yield trial & 5821 & 5250 & 10.87 \\
2010 & On-station yield trial & 5604 & 5074 & 10.44 \\
2009 & On-farm trial (4 location) 20 farmer's field & 6037 & 5119 & 17.93 \\
2010 & On-farm trial (4 location) 20 farmer's field & 6005 & 5337 & 12.51 \\
\hline
\end{tabular}

farmer's field during 2009 and 2010 through on-farm trials and gave $17.93 \%$ and $12.51 \%$ more yield than the farmer's choice variety Swarna.

State Variety Release Committee, West Bengal, India released IET 20760 as BNKR-1 (Dhiren) in 2011 for cultivation in irrigated areas under transplanted condition in West Bengal. BNKR-1 (Dhiren) is a non-lodging, non-shattering and late maturing variety. Its average yield is 5000-5500 kg ha ${ }^{-1}$ and yield potentiality $10,793 \mathrm{~kg} \mathrm{ha}^{-1}$ (at Port Blair). Details morphological characteristics given in Table 3. It was tested through National Screening Nurseries for its reaction to different pest and diseases during kharif
2008 and 2009. It showed moderate resistant against leaf blast, neck blast, sheath rot, brown spot and leaf folder.

BNKR-1 (Dhiren) yielding higher than the most popular HYV rice variety Swarna of same maturity group (late) is a boon for the farmer's of West Bengal, India. There is a great demand for seed of BNKR-1 (Dhiren) from farming community and gaining popularity day by day among the farmers of Bankura, Purulia and Paschim Medinipur districts of West Bengal. This variety has the potential to be an alternative/replacement for MTU 7029 (Swarna) in irrigated areas of West Bengal. 
Table 3. Description of the rice variety BNKR - 1 (Dhiren) [IET 20760].

\begin{tabular}{lll}
\hline 1 & Plant height & $129 \mathrm{~cm}$ \\
2 & Plant Type & Semi-erect \\
3 & No. of tillers / Plant & 12.5 \\
4 & Leaf : Intensity of green colour & Light green \\
5 & Average length of flag leaf & $30.85 \mathrm{~cm}$ \\
6 & Average length of second leaf & $43.5 \mathrm{~cm}$ \\
7 & Average breadth of flag leaf & $1.69 \mathrm{~cm}$ \\
8 & Average breadth of second leaf & $2.08 \mathrm{~cm}$ \\
9 & Flowering duration (50\% flowering) & 116 days \\
10 & Average no. of grains per panicle & 236 \\
11 & Awning & Awnless \\
12 & Panicle exertion & Well exerted \\
13 & Average length of panicle & $25.7 \mathrm{~cm}$ \\
14 & Lodging characteristics & Non lodging \\
15 & 1000 Grain Weight & $22.92 \mathrm{gms}$ \\
16 & Kernel length (mm) & $5.05 \mathrm{~mm}$ \\
17 & Kernel breadth (mm) & $2.48 \mathrm{~mm}$ \\
18 & L/ B ratio & 2.036 \\
19 & Kernel appearance & Translucent, grain chalkiness - VOC \\
20 & Grain type & SB \\
21 & Milling recovery & $69.70 \%$ \\
22 & Amylose Content & $22.50 \%$ \\
\hline & & \\
& &
\end{tabular}

\section{REFERENCES}

Saha, S., Dutta, A., Ghosh, S. and Mallick, G.K. (2008) Rice diseases in red and lateritic zones of West Bengal, India. Environ. Ecol. , 26 (4) 1691 -1692

Sahai, V.N., Ghosh, S., Choudhary, R.C. (2004). Rajendra Mahsuri-1, a potentially high-yielding rice variety for medium and shallow lowland ecosystems of Bihar, India, International Rice Research Note 29.1,PP-26

Sharma, R.K., Bhatt, J.C., Gupta, H.S. (2003). "Vivek Dhan 82: a high yielding, blast-resistant irrigated rice variety for the Indian Himalaya. International Rice Research Note, 28.2 PP-24
Shobha Rani N, Vara Prasad, G.S., Subba Rao L.V., Sudharshan I., Hari Prasad A.S., Prasad A.S.R., Ram T., Ravindra Babu V., Padmavathi G., Bhadana Vijaipal, Suneetha K. and Viraktamath B.C. (2011). High yielding rice varieties of India. Directorate of Rice Research, Hyderabad 500030, Andhra Pradesh, India, pp-2

Thakur, R., Singh, N.K., Mishra, S.B., Singh, A.K. and Singh, K.K. (2003). Santosh-a high yielding variety for the rainfed lowland of Bihar, India developed through participatory breeding. International Rice Research Note, 28.2 PP-25 